\title{
Exporting Behavior of Foreign Affiliates: Theory and Evidence*
}

\author{
Jiangyong $\mathrm{Lu}^{\mathrm{a}}$, Yi Lu ${ }^{\mathrm{b}}$, and Zhigang $\mathrm{Tao}^{\mathrm{b}}$ \\ ${ }^{a}$ Peking University \\ b University of Hong Kong
}

March 2010

\begin{abstract}
Firms have increasingly conducted different stages of production in different countries. In particular, they may set up operations in lowcost countries (those operations are referred to as foreign affiliates in those countries) either as platforms for export or serving the growing markets there. What is the exporting behavior of foreign affiliates? In this paper, using data from China, we find that among foreign affiliates exporters are less productive than non-exporters. We then offer a theoretical explanation by incorporating into the standard firm heterogeneity model the possibility that firms could have different stages of production in different countries.
\end{abstract}

Keywords: Foreign Affiliates, Exporting Behavior, Firm Heterogeneity

JEL Codes: F12, F23, L22, D24, L60

*We would to thank a co-editor and two anonymous referees for valuable comments and suggestions, and Linhui Yu for expert research assistance. The first author acknowledges financial support from National Natural Science Foundation of China (70703017) and Guanghua Leadership Institute in Collaboration with Cisco, and the other two authors thank Hong Kong Research Grants Council and University of Hong Kong for financial support. 


\section{Introduction}

Since mid-1990s, there has been increasing evidence suggesting that exporting behavior varies significantly across firms even after controlling for industry effects (see, for example, Bernard and Jensen, 1995, 1999). A unanimous finding in the literature is that exporters are more productive than nonexporters (called export premium), e.g., Bernard and Jensen (1995, 1999, 2004) for the study of the United States; Bernard and Wagner (1997) for the study of Germany; Clerides, Lach, and Tybout (1998) for the study of Columbia, Mexico and Morocco; and Greenaway and Kneller (2004) for the study of the United Kingdom. A dominant theoretical explanation for the export premium result is based on the existence of fixed costs of exporting, under which more productive firms self-select to become exporters (e.g., Bernard, Eaton, Jensen, and Kortum, 2003; Melitz, 2003; and Bernard, Redding, and Schott, 2007). ${ }^{1}$

However, almost all the existing studies implicitly focus on the exporting behavior of domestic firms, or at least they do not explicitly differentiate domestic firms from foreign affiliates (foreign-invested firms operating in those countries). ${ }^{2}$ As transport and communications costs decrease, firms have increasingly conducted different stages of production in different countries. In particular, firms may set up their production plants in low-cost countries such as Brazil, China, India, and Russia as their export platforms, which is referred to as vertical foreign direct investment (or FDI) in the literature (e.g., Hummels, Ishii, and Yi, 2001; Yeaple, 2003; Yi, 2003; Grossman, Helpman, and Szeidl, 2006; Ekholm, Forslid, and Markusen, 2007). ${ }^{3}$ As a result, a significant percentage of export from those low-cost countries is made by foreign affiliates in the countries. Is the exporting behavior of foreign affiliates similar to that of domestic firms? In this paper, we fill the void by investigating empirically the exporting behavior of foreign affiliates using data from China, and then offer a theoretical explanation for the empirical findings. ${ }^{4}$

\footnotetext{
${ }^{1}$ Some recent studies, however, show that there also exists learning from exporting (e.g., Blalock and Gertler, 2004; Van Biesebroeck, 2005; De Loecker, 2007).

${ }^{2}$ Baldwin and $\mathrm{Gu}$ (2003) and Kneller and Pisu (2004) are two exceptions, using data from Canada and UK respectively, but neither has found any significant difference between domestic firms and foreign affiliates. Presumably, the sample sizes of foreign affiliates in these two countries are not large enough.

${ }^{3}$ It should be pointed out that foreign multinationals may also have direct investment in those countries to serve the growing markets there, and such investment is referred to as horizontal FDI in the literature (Markusen, 2002).

${ }^{4}$ Here exporting behavior refers to how foreign affiliates with different productivity choose to set up different stages of production in different countries and the associated export status.
} 
China offers an ideal setting to investigate this issue. Between 1979 and 2005, China has attracted more than US $\$ 1,285$ billion FDI (China Statistical Yearbook, 2006). Meanwhile, China was the second largest exporter in the world in 2007 (The World Factbook, 2007). More importantly, much of China's export has been made by foreign affiliates, not China's domestic firms (Manova and Zhang, 2008).

Our dataset comes from annual surveys of manufacturing firms conducted by the National Bureau of Statistics of China for the period of 1998 to 2005. We find that among China's domestic firms, exporters are indeed more productive than non-exporters, similar to the unanimous finding in the existing literature. Surprisingly, for foreign affiliates in China, exporters are found to be less productive. Moreover, we find that, among foreign affiliates, those selling all their output in China have the highest productivity, followed by those having sales in China and also exporting some of their output, and finally those exporting all their output. These findings remain robust to a number of sensitivity checks, such as an alternative measure of productivity, an alternative estimation method, an alternative definition of foreign affiliates, exclusion of outlying observations, inclusion of firm size as an additional control variable, and estimation of productivity separately for domestic firms and foreign affiliates.

We next construct a simple model to explain the exporting behavior of foreign affiliates. It is a standard $2 \times 2 \times 2$ trade model à la Grossman, Helpman, and Szeidl (2006), with two sectors (i.e., homogenous good sector and differentiated goods sector), two factors (i.e., skilled labor and unskilled labor), and two countries (i.e., China and the United States). Similar to Melitz (2003)'s setting, firms differ in their productivity, which is drawn from a common distribution. There are two vertically-related stages of the production process, i.e., design and manufacturing. The United States has a cost advantage in design whereas China has a cost advantage in manufacturing. For simplicity, we assume there is a negligible transport cost for shipping the design product to the manufacturing plant, thereby the design stage is always located in the United States. But the transport cost for shipping the final product to an abroad market is non-trivial, thereby firms can choose to set up their manufacturing plant in either the United States, or China, or both. Firms can also choose to sell their output in the United States, or China, or both. There is a fixed cost for setting up a manufacturing plant in any of these two countries, and also a fixed cost of selling in any of these two markets.

Under this framework, there are nine possible strategies in organization choice and market orientation, i.e., manufacturing plant in either the United States, or China, or both, and selling in either the United States, or China, or 
both. We can show that in equilibrium there are four strategies corresponding to the three types of foreign affiliates observed in our dataset: foreign affiliates selling all their output in China, those exporting all their output, and those having sales in China and exporting some of their output. The comparison among these four strategies in terms of their productivity offers an explanation for the puzzling exporting behavior of foreign affiliates (i.e., exporters have lower productivity than non-exporters among foreign affiliates). ${ }^{5}$ Intuitively, the choice among the different strategies depends on the trade-off between fixed costs and production efficiency (determined by the size of the markets and the unit cost of production). Compare, for example, the strategy of exporting all their output with the strategy of having sales in China and exporting some of their output. The latter strategy gains an extra market (i.e., the market in China) but needs to incur a fixed cost of selling in China. Clearly the more productive foreign affiliates choose the latter strategy given the trade-off between fixed costs and market size.

Our paper builds upon a large literature of firm heterogeneity and trade. What differentiates our paper from the literature is its focus on the exporting behavior of foreign affiliates, which are increasingly prevalent in today's global economy. We show that the relation between productivity and exporting behavior for foreign affiliates is just the opposite of the unanimous finding in the literature which focuses on domestic firms. Theoretically, by incorporating into the standard firm heterogeneity model (Melitz, 2003) the possibility that firms could set up different stages of production in different countries à la Grossman, Helpman, and Szeidl (2006), we are able to obtain richer predictions on the relation between productivity and exporting behavior.

The remainder of the paper is structured as follows. Section 2 describes data, and Section 3 presents our empirical findings. In Section 4, we offer a theoretical model to explain our empirical findings. The paper concludes with Section 5.

\section{Data and Descriptive Statistics}

Our data is from annual surveys of manufacturing firms conducted by the National Bureau of Statistics of China for the period of 1998 to 2005. These annual surveys covered all state-owned enterprises, and those non-stateowned enterprises with annual sales of five million Chinese currency (about

\footnotetext{
${ }^{5}$ Our framework can also show that, for domestic firms in China, it is the more productive ones that export, which is consistent with our empirical findings and in line with the predictions of other theoretical models in the literature.
} 
US $\$ 650,000)$ or more. The data provides detailed information on firms' identification, operations and performance, including firm ownership and export, which are of special interest to this study. As reported in Table 1a, the number of manufacturing firms with valid information of total output and export varies from over 140,000 in the late 1990s to over 243,000 in 2005 . The percentage of China's total exports contributed by firms in our dataset was just below $70 \%$ in late 1990s, and was as high as $76 \%$ in 2005, indicating that our data set is highly comprehensive.

The focus of this study is on the exporting behavior of foreign affiliates. According to the classification of the National Bureau of Statistics of China, foreign affiliates are firms in which $25 \%$ or more equity shares are held by foreign multinationals. ${ }^{6}$ We use this definition of foreign affiliates in most of our analysis. As a robustness check, we also use firm's ownership type reported in the dataset to define foreign affiliates. Specifically, there are five types of ownership: state-owned firms, collectively-owned firms, joint-stock companies, privately-owned firms, and foreign-invested firms. We treat firms with foreign-invested ownership type as foreign affiliates.

As shown in Table 1b, over the period of 1998 to 2005, an average of $27.14 \%$ of China's manufacturing firms (including both domestic firms and foreign affiliates) exported. Foreign affiliates are much more export-oriented than do domestic firms: $62.95 \%$ of foreign affiliates are exporters whereas the corresponding number for domestic firms is $18.68 \%$. The difference between these two types of firms in export intensity is even greater: the percentage of export in total output hovered around $10.48 \%$ for China's domestic firms over the sample period, whereas that for foreign affiliates increased from $39.23 \%$ in 1998 to $44.60 \%$ in $2005 .^{7}$ Taken together, the percentage of China's total export by foreign affiliates increased from $59.66 \%$ in 1998 to $70.98 \%$ in 2005 , showing that foreign affiliates are the main driver behind the spectacular rise of China's export.

Exporting behavior of China's manufacturing firms varies significantly across its geographic areas. ${ }^{8}$ As shown in Table 1c, foreign affiliates located

\footnotetext{
${ }^{6}$ Our main results remain robust if firms from Hong Kong, Macau and Taiwan are excluded from the sample.

${ }^{7}$ From the 2002 U.S. census of manufacturers, it is found that $20 \%$ of U.S. manufacturing plants exported and the exporters shipped $15 \%$ of their output abroad (Bernard, Jensen, Redding, and Schott, 2007). The percentage of exporters in the French manufacturing industries is also $20 \%$, though the export intensity is lower at $10 \%$ (Eaton, Kortum and Kramarz, 2004).

${ }^{8}$ During the sample period, China's administrative boundaries and consequently its county, city, or even provincial codes experienced some changes. For example, new counties were established, while existing counties were combined into larger ones or even elevated to cities. From 1998 to 2005, the number of counties in China increased from 2,496 to 2,862 (a
} 
in China's coastal area have higher propensities to export and higher export intensities than those located in China's central area, which in turn have higher propensities to export and higher export intensities than those located in China's western area. Presumably, foreign affiliates located in the central and western areas focus more on China's domestic markets than their counterparts located in the coastal area. Meanwhile, China's domestic firms have lower propensities to export and lower export intensities than foreign affiliates in each of the three areas. There is little difference in the propensity to export between domestic firms located in the coastal area and those in the central area, though the former have much higher export intensity than the latter. Overall, $93.8 \%$ percent of China's total exports are made by firms located in the coastal area, and $71.4 \%$ of these exports are from foreign affiliates in this area.

Besides the differences across geographic areas, there are also significant variations in exporting behavior across industries. ${ }^{9}$ As the technology content of China's exports has become an interesting topic, we look at the patterns of exporting behavior across the low-tech, medium-tech, and high-tech industries classified according to the OECD standard. Several patterns emerge from the results summarized in Table 1d: (1) $51.8 \%$ of China's export is from the high-tech industries, followed by $32.0 \%$ in the low-tech industries and $16.2 \%$ in the medium-tech industries. Given China's comparative advantage in low-tech industries, it seems puzzling that China exports large amounts of high-tech goods as well as low-tech goods (Rodrik, 2006; Wang and Wei, 2008; $\mathrm{Lu}$ and $\mathrm{Xu}, 2009$ ). (2) In the high-tech industries and lowtech industries, compared with the national averages, both foreign affiliates and domestic firms have higher propensities to export and higher export intensities, accounting for the high export in these two types of industries.

total of 366), while the number of changes in the county codes was 648. From 1998 to 2005, the number of prefecture-level cities or above increased from 231 (4 municipalities, 15 vice provincial cities, and 212 prefecture-level cities) to 287 (4 municipalities, 15 vice provincial cities, and 268 prefecture-level cities). Using the 1999 National Standard (promulgated at the end of 1998 and called GB/T 2260-1999) as the benchmark codes, we convert the regional codes of all the firms to these benchmark codes to achieve consistency for the regional codes in the whole sample period.

${ }^{9}$ In 2003, a new classification system for industry codes (called GB/T 4754-2002) was adopted to replace the old classification system (called GB/T 4754-1994) that had been used from 1995 to 2002 . To achieve consistency in the industry codes for the whole sample period (1998-2005), we convert the industry codes in the 2003-2005 data to the old classification system by using a concordance table (in the case of a new four-digit code corresponding to an old four-digit code or several new four-digit codes corresponding to an old four-digit code) or by assigning a new code for an old code based on product information (in the case of several old four-digit codes corresponding to a new 4-digit code). 
(3) Foreign affiliates are responsible for $82.8 \%$ percentage of export in the high-tech industries, indicating that much of the worry about the increasing competitiveness of China's exports in the high-tech industries might well be misguided as export in the high-tech industries are made by foreign affiliates rather than China's domestic firms.

Table 1e provides further descriptive statistics regarding the exporting behavior of foreign affiliates, which is the focus of this paper. Over the period of 1998-2005, on average, $37.05 \%$ of foreign affiliates sell all their output in China, $39.22 \%$ of foreign affiliates have sales in China and also export some of their output, and $23.73 \%$ of foreign affiliates export all their output. Meanwhile, during this period, the percentage of foreign affiliates having both sales in China and export increases at the expenses of foreign affiliates selling all their output in China and those exporting all their output.

\section{Empirical Analysis}

In this section, we empirically investigate the exporting behavior of foreign affiliates in China. The key performance indicator used in the literature to document the possible difference between exporters and non-exporters is the total factor productivity (TFP), e.g., Bernard and Jensen (1995, 1999, 2004), Bernard and Wagner (1997), Clerides, Lach, and Tybout (1998), Greenaway and Kneller (2004), and De Loecker (2007). Specifically, we estimate the following equation:

$$
\text { TFP }_{\text {firt }}=\alpha+\beta \cdot \text { Export }_{\text {firt }}+\delta_{i}+\eta_{r}+\lambda_{t}+\varepsilon_{\text {firt }}
$$

where $T F P_{\text {firt }}$ is the TFP of firm $f$ in industry $i$, region $r$ and year $t$; Export $_{\text {firt }}$ is a dummy variable indicating whether firm $f$ is an exporter; $\delta_{i}, \eta_{r}$ and $\lambda_{t}$ are 4-digit industry dummy, region dummy, ${ }^{10}$ and year dummy, respectively; and $\varepsilon_{\text {firt }}$ is the error term.

Four variables are used to estimate TFP: output, labor, capital, and intermediate inputs. After deleting observations with missing information related to these four variables, we obtain a balanced sample of 31,057 firms that appeared in the dataset for all eight years from 1998 to 2005. An additional 51 firms are deleted because of missing information about export. As the focus of our study is on the exporting behavior of foreign affiliates, we further exclude firms that switched, one time or more, from foreign affiliates to domestic firms, or vice versa. Specifically, a total of 3,158 firms are deleted

\footnotetext{
${ }^{10}$ Region here refers to 22 provinces, 4 province-level municipalities, and 5 minority autonomous regions in China.
} 
when foreign affiliates are defined as firms with $25 \%$ or more equity shares held by foreign multinationals, whereas a total of 1,104 firms are deleted when foreign affiliates are defined by their reported ownership type.

We first use the ordinary-least-squares (OLS) regression method to estimate the TFP for firms in each 2-digit industry and each year (denoted by TFP OLS) (see also Bernard and Jensen, 1999). Specifically, we use the constant value of output, and deflate capital by the fixed-assets investment price index and intermediate inputs by the producer price index. The OLS estimation of TFP, however, may suffer from the simultaneity problem, specifically, input choices could be endogenously determined by unobservable productivity shocks. This may lead to an upward bias in the estimation coefficients of more variable inputs such as labor (Van Biesebroeck, 2007, 2008).

We therefore use an alternative estimation method, i.e., Levinsohn and Petrin (2003)'s TFP estimation method (denoted by TFP LP), in which the intermediate inputs are used as a proxy for unobservable productivity shocks to deal with the simultaneity problem. ${ }^{11}$ As Levinsohn and Petrin (2003)'s TFP estimation method relies on the panel estimation of firms that remain in the same industries throughout the estimation period, we therefore delete those firms that experienced changes in their 2-digit industry affiliations during the sample period. We end up with a reduced sample of 22,549 firms. The average coefficients for labor, capital and intermediate inputs are 0.055, 0.032 and 0.743 respectively (the estimated coefficients of inputs for each 2-digit industry are available online). For comparison, we also use the OLS method to estimate TFP for this reduced sample in each 2-digit industry and each year (denoted by TFP OLS ${ }^{R}$ ) (results are available online). The average coefficients for labor, capital and intermediate inputs under the OLS estimation are 0.062, 0.036 and 0.891 respectively. Consistent with the findings in Levinsohn and Petrin (2003) and Van Biesebroeck (2008), the coefficient for labor is over-estimated under the OLS method.

Moreover, as a further robustness check, we re-estimate the TFP at more disaggregated industry level. Specifically, we use the OLS method to estimate the TFP in each 3-digit industry and each year (denoted by TFP OLS ${ }^{3 D}$ ), and the Levinsohn and Petrin (2003)'s method in each 3-digit industry (denoted by $\left.T F P L P^{3 D}\right) .{ }^{12}$

\footnotetext{
${ }^{11}$ An alternative method for dealing with the endogeneity problem is Olley and Pakes method (1996), which uses investment as a proxy for unobservable productivity shocks. However, there is a large number of missing information on investment in our dataset (i.e, only 5,943 firms out of 27,848 have positive investment). Therefore Olley and Pakes method is not econometrically efficient in our case.

${ }^{12}$ In the OLS estimation, as some industry-year cells have very few observations, we
} 
Benchmark regression results for equation (1) are reported in Table 2. As shown in Column 1, when all firms are included in the regression analysis, Export $_{\text {firt }}$ has a positive and statistically significant effect on TFP estimated using the OLS method, which is similar to the findings reported in the literature. Next, we carry out the analysis for the two sub-samples, one for domestic firms and the other for foreign affiliates, and report the results in Columns 2-3 of Table 2, respectively. Surprisingly, we find contrasting patterns of exporting behavior between domestic firms and foreign affiliates.

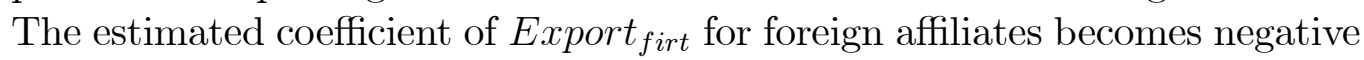
and statistically significant, though that for domestic firms remains positive and statistically significant. The negative coefficient of Export firt $_{\text {for foreign }}$ affiliates remains robust when the TFP is estimated using Levinsohn and Petrin (2003)'s method (Column 4 of Table 2); when the TFP is estimated using the OLS method for the same reduced sample as used in the Levinsohn and Petrin (2003)'s estimation (Column 5 of Table 2); and when the TFP is estimated using the OLS and the Levinsohn and Petrin (2003)'s method at the 3-digit industry level (Columns 6-7 of Table 2).

As there are three types of foreign affiliates (i.e., foreign affiliates with domestic sales only, those with both domestic sales and export, and those with export only), we therefore replace the export dummy of equation (1) by two dummy variables: one for foreign affiliates with domestic sales only (denoted by Domestic Sales Only firt), and the other for foreign affiliates

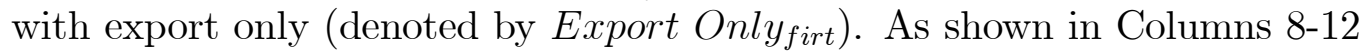
of Table 2, the coefficients for Domestic Sales Only firt are positive albeit statistically insignificant when the TFP is estimated using the OLS method, but they are both positive and statistically significant when the TFP is estimated using the Levinsohn and Petrin (2003)'s method. Meanwhile, the coefficients for Export Only firt are always negative and statistically significant. These results offer a finer ranking of foreign affiliates in terms of their productivity. Specifically, foreign affiliates with domestic sales only have the highest productivity, followed by those with both domestic sales and export, and finally those with export only. ${ }^{13}$

Note that our analysis thus far is based on the balanced sample of firms for the period of 1998-2005. As China continues its rapid economic growth, there

exclude those cells with observations below 10 to reduce possible estimation biases. In the Levinsohn and Petrin (2003)'s estimation, we exclude those firms that changed their 3 -digit industry affiliations during the sample period.

${ }^{13}$ The ranking of the average TFP (estimated using Levinsohn and Petrin (2003)'s method) among these three types of foreign affiliates in each of the twenty-eight two-digit manufacturing industries is in general consistent with our regression results (available online). 
has been a surge of foreign direct investment aiming at capturing the Chinese market in more recent years. Thus it would be interesting to investigate if newly established foreign affiliates behave differently from those in the balanced sample. We then use the full sample of firms in 2005, and report the regression results in Table 3. It is found that the coefficient of dummy variable Export Only $_{\text {firt }}$ remains negative albeit statistically insignificant (Column 1 of Table 3), generally consistent with our results in Table 2. In Column 2, we replace the dummy variable Export Only firt by two other dummy variables (Domestic Sales Only firt, and Export Only firt), and find that the coefficients of these two dummy variables are both negative and statistically significant. These results imply that foreign affiliates exporting all their output are less productive than those having both sales in China and exporting some of their output (consistent with our results in Table 2), but that foreign affiliates selling all output in China become less productive than those having both sales in China and exporting some of their output (in contrast with those in Table 2). As our theoretical analysis will show, there are two types of foreign affiliates selling all their output in China, one focuses exclusively on the Chinese market and the other has presence in both Chinese and world markets. The contrasting finding between Table 2 and Table 3 can be explained as that foreign affiliates entering into China after 1998 may predominantly focus exclusively on the growing market in China, thereby overshadowing those older foreign affiliates having presence in both the Chinese and world markets.

In the remaining part of this section, we conduct a series of robustness checks regarding the relation between firm productivity and exporting behavior for foreign affiliates. To save space, we only report the results using the TFP estimated by Levinsohn and Petrin (2003)'s method as the dependent variable and using the balanced sample for the period 1998-2005.

First, we use an alternative definition of foreign affiliates - the official ownership type reported by the firm in the survey - instead of that implied by foreign equity ownership. As shown in Column 1 of Table 4, our main results remain robust to this definition of foreign affiliates.

Second, to address the concern that our results could be driven by some outlying observations, we exclude the top and bottom $1 \%$ observations in our sample and repeat the analysis. As shown in Column 2 of Table 4, our main results remain robust to the exclusion of outlying observations.

Third, to make sure that our results are not entirely driven by firm size, we incorporate Firm Size (defined as the logarithm of capital) in the regression analysis. The result reported in Column 3 of Table 4 reveal that our findings remain robust to the inclusion of Firm Size.

Lastly, to deal with the concern that foreign affiliates may have different 
production functions from domestic firms, we re-estimate the TFP of foreign affiliates using only the sub-sample of foreign affiliates. As shown in Column 4 of Table 4, our main findings remain robust to this alternative estimation of TFP.

Taken together, the empirical analysis in this section shows that for foreign affiliates, those exporting all their output are less productive than those having both sales in China and also exporting some of their output, which in turn are generally less productive than those selling all their output in China. To the best of our knowledge, this is the first study reporting that exporters are less productive than non-exporters in the literature. Our study is also one of the few studies on the exporting behavior of foreign affiliates.

\section{Theoretical Analysis}

In this section, we build a simple model based on Grossman, Helpman, and Szeidl (2006) to explain our empirical findings regarding the exporting behavior of foreign affiliates documented in the previous section.

\subsection{Model Setup}

It is a standard $2 \times 2 \times 2$ trade model, in which there are two countries (i.e., China $(C)$ and the United States $(A)$ ), two sectors (i.e., a homogeneous good $(X)$ produced with a constant return to scale technology and a continuum of differentiated goods $(Y)$ produced with an increasing return to scale technology), and two factors (i.e., skilled labor and unskilled labor).

Following the literature (i.e., Dixit and Stiglitz, 1977), we take the homogeneous good $(X)$ as a numéraire and assume the utility function for the differentiated goods $(Y)$ to be a constant elasticity of substitution function. Then the demand function for any differentiated good in country $l$ can be derived as:

$$
y^{l}=\alpha^{\frac{-\alpha}{1-\alpha}} I^{l}\left(p^{l}\right)^{\frac{-1}{1-\alpha}}, 0<\alpha<1
$$

where $l \in\{A, C\}$ is the index for the country; $y^{l}$ is the consumption of the differentiated good in country $l ; I^{l}$ is the aggregate demand level (or market size) in country $l$; and $p^{l}$ is the price of the differentiated good in country $l$.

There are two vertically-related stages for producing any variety of the differentiated goods, i.e., design $(d)$ and manufacturing $(m)$. It is assumed that the design stage is more intensive in the usage of skilled labor than does the manufacturing stage, and that the United States has a lower wage of skilled labor but a higher wage of unskilled labor than does China. Thus 
the United States has a cost-advantage in design while China has a costadvantage in manufacturing, i.e., the design cost in the United States $\left(d^{A}\right)$ is lower than that in China $\left(d^{C}\right)$, but the manufacturing cost in the United States $\left(m^{A}\right)$ in higher than that in China $\left(m^{C}\right)$. The unit cost for producing the final product is then given by $c\left(d^{l}, m^{l}\right) / \theta$, where the first term of $c(.,$. indicating the design cost and the second term indicating the manufacturing cost, and $\theta$ is the firm-specific productivity measure, which is drawn from a common distribution as in Melitz (2003).

There is a fixed cost associated with setting up a plant of design or manufacturing in any of the two countries. We assume that the fixed cost uses the same intensity of skilled labor and unskilled labor as the unit production cost (for the use of same assumption, see for example Baldwin, Forslid, Martin, Ottaviano, and Robert-Nicoud, 2003; Bernard, Redding, and Schott, 2007). Thus the fixed cost of setting up a design plant in the United States $\left(f_{d}^{A}\right)$ is lower than that in China $\left(f_{d}^{C}\right)$ whereas the fixed cost of setting up a manufacturing plant in the United States $\left(f_{m}^{A}\right)$ in higher than that in China $\left(f_{m}^{C}\right)$.

There is also a fixed cost involved with the sales of the final product, e.g., the costs of setting up a distribution network. To take into account of the possible heterogeneity in selling costs, we assume that the fixed cost of selling the differentiated good in any of the two countries is $f_{s}$ if the manufacturing of the final product takes place in the same country, but is increased to $f_{s}+\Delta f_{s}$ if the manufacturing takes place in a different country.

It is assumed that the transport cost for the design product is negligible (e.g., the design product could be transmitted by E-mail or sent by express mail), but there is a non-zero transport cost for shipping the final product to an abroad market. Specifically, the transport cost takes the form of an iceberg cost, i.e., one needs $t>1$ units of final product in order to ship 1 unit to an abroad market. It is further assumed that the transport cost for the final product is non-trivial, i.e., for the market in the United States, the unit cost for the final product is higher when the final product is imported from China than when it is produced in the United States (called the tariffjumping assumption). Without this assumption, manufacturing is always conducted in China, which makes the analysis less interesting. ${ }^{14}$

A firm needs to make two decisions, one is where to set up its design and manufacturing plants and the other is where to sell its final product. As there is a negligible transport cost for the design product and the United

\footnotetext{
${ }^{14}$ More generally, if this assumption is not satisfied, production processes are completely disintegrated with each production stage located in the country with the comparative advantage.
} 
States has cost-advantages in both the fixed cost and the unit production cost for the design stage, the design plant is always located in the United States. ${ }^{15}$ However, for the manufacturing plant, it could be located in the United States only $(A)$, China only $(C)$, or both the United States and China $(A C)$. Meanwhile, a firm can sell its final product in the United States only $(A)$, China only $(C)$, or both the United States and China $(A C)$.

Let $\sigma(., .,$.$) denote a strategy for the firm, where the first entry represents$ the location of the design plant, the second entry represents the location of the manufacturing plant, and the last entry represents the location of the final product market. There are altogether nine possible strategies: $\sigma(A, A, A)$, $\sigma(A, A, C), \sigma(A, A, A C), \sigma(A, C, A), \sigma(A, C, C), \sigma(A, C, A C), \sigma(A, A C, A)$, $\sigma(A, A C, C)$, and $\sigma(A, A C, A C)$.

\subsection{Equilibrium Strategy}

Given the above setup, we can derive the equilibrium profit function for each possible strategy $(\pi(\sigma))$. In analyzing the optimal strategy, we adopt the iterated elimination method, i.e., once a possible strategy is dominated by another, it is eliminated from the choice.

Step 1: $\sigma(A, A, C), \sigma(A, A C, A)$, and $\sigma(A, A C, C)$ are dominated strategies.

$\sigma(A, A, C)$ (design and manufacturing in the United States, and selling in China) is dominated by $\sigma(A, C, C)$ (design in the United States, and manufacturing and selling in China), because the latter enjoys a lower manufacturing cost and does not need to incur any transport cost for the final product.

$\sigma(A, A C, A)$ (design in the United States, manufacturing in both the United States and China, and selling in the United States) is dominated by either $\sigma(A, A, A)$ (design, manufacturing and selling in the United States). Because of the tariff-jumping assumption, the market in the United States is only served by the manufacturing plant in the United States. As a result, the former strategy incurs a redundant fixed cost of setting up a manufacturing plant in China.

$\sigma(A, A C, C)$ (design in the United States, manufacturing in both the United States and China, and selling in China) is dominated by $\sigma(A, C, C)$ (design in the United States, and manufacturing and selling in China). In this case, the market in China is only served by the manufacturing plant

\footnotetext{
${ }^{15}$ It is commonly assumed in the literature that the design stage is always located in the United States and firms only decide where to set up their manufacturing plants, e.g., Antras (2003), Antras and Helpman (2004), and Helpman and Grossman (2005).
} 
in China due to the lower manufacturing cost in China and the saving of transport costs. As a result, the former strategy incurs a redundant fixed cost of setting up a manufacturing plant in the United States.

Step 2: $\sigma(A, A, A)$ and $\sigma(A, A, A C)$ are not observed in our dataset.

Both $\sigma(A, A, A)$ (design, manufacturing and selling in the United States) and $\sigma(A, A, A C)$ (design and manufacturing in the United States, and selling in both the United States and China) represent the American domestic firms as all their production takes place in the United States. In the first case, the firm sells all its output in the United States, and in the second case the firm exports some of its output to China (to China it is import). Thus, these two cases are not foreign affiliates in China and not observed in our dataset.

Step 3: the comparison among $\sigma(A, C, C), \sigma(A, C, A), \sigma(A, C, A C)$, and $\sigma(A, A C, A C)$.

Now we are left with only four possible strategies: $\sigma(A, C, C)$ represents the strategy with design in the United States, manufacturing in China, and selling in China; $\sigma(A, C, A)$ represents the strategy with design in the United States, manufacturing in China, and selling in the United States; $\sigma(A, C, A C)$ is the strategy with design in the United States, manufacturing in China, and selling in both the United States and China; and $\sigma(A, A C, A C)$ is the strategy with design in the United States, manufacturing and selling in both the United States and China (and due to the tariff-jumping assumption, the manufacturing plant in the United States serves only the market there while the manufacturing plant in China serves only the Chinese market).

The profit functions for foreign affiliates adopting these four strategies can be shown as follows:

$$
\left\{\begin{array}{c}
\pi(\sigma(A, C, C))=\frac{(1-\alpha) I^{C}}{C\left(d^{A}, m^{C}\right)} \Theta-\left(f_{d}^{A}+f_{m}^{C}+f_{s}\right) \\
\pi(\sigma(A, C, A))=\frac{(1-\alpha) \frac{I^{A}}{T}}{C\left(d^{A}, m^{C}\right)}-\left(f_{d}^{A}+f_{m}^{C}+f_{s}+\Delta f_{s}\right) \\
\pi(\sigma(A, C, A C))=\frac{(1-\alpha)\left(I^{C}+\frac{I^{A}}{T}\right)}{C\left(d^{A}, m^{C}\right)} \Theta-\left(f_{d}^{A}+f_{m}^{C}+2 f_{s}+\Delta f_{s}\right) \\
\pi(\sigma(A, A C, A C))=\left(\frac{(1-\alpha) I^{C}}{C\left(d^{A}, m^{C}\right)}+\frac{(1-\alpha) I^{A}}{C\left(d^{A}, m^{A}\right)}\right) \Theta-\left(f_{d}^{A}+f_{m}^{A}+f_{m}^{C}+2 f_{s}\right)
\end{array}\right.
$$

where $\Theta \equiv \theta^{\frac{\alpha}{1-\alpha}}$ is a monotonic transform of productivity $\theta ; C(.,.) \equiv$ $c(., .)^{\frac{\alpha}{1-\alpha}}$ is a monotonic transform of unit production cost $c(.,.) ; T \equiv t^{\frac{\alpha}{1-\alpha}}$ is a monotonic transform of transport cost $t$; and $I^{l}$ is the market size in country $l, l \in\{A, C\}$.

It is clear that the profit function for each of these four strategies is a linear function of $\Theta$, and it just differs in the slope term (denoted by $\phi$ ) and the intercept term (the negative of the fixed costs, denoted by $F$ ) across the different strategies (see the Figure for illustration). 
The comparison of the fixed costs across the four strategies is straightforward. Specifically, as strategy $\sigma(A, C, C)$ has design in the United States and manufacturing in China to serve the market in China, the fixed costs are equal to $F_{\sigma(A, C, C)} \equiv f_{d}^{A}+f_{m}^{C}+f_{s}$. Strategy $\sigma(A, C, A)$ involves design in the United States but manufacturing in China to serve the market in the United States, and so the fixed costs increase to $F_{\sigma(A, C, A)} \equiv f_{d}^{A}+f_{m}^{C}+f_{s}+\Delta f_{s}$ due to the extra selling costs involved when the market is served by manufacturing plant located in a different country. Strategy $\sigma(A, C, A C)$ has design in the United States and manufacturing in China to serve both the market in China and the market in the United States, and its fixed costs increase further to $F_{\sigma(A, C, A C)} \equiv f_{d}^{A}+f_{m}^{C}+2 f_{s}+\Delta f_{s}$ due to the additional selling cost in China. Finally, strategy $\sigma(A, A C, A C)$ has design in the United States, and manufacturing plants in both the United States and China to serve the respective markets, and thus, compared with strategy $\sigma(A, C, A C)$, there is an increase in the manufacturing costs in the United States but a decrease in the selling costs in the United States (i.e., $F_{\sigma(A, A C, A C)} \equiv f_{d}^{A}+f_{m}^{A}+f_{m}^{C}+2 f_{s}$ ). It is expected that $F_{\sigma(A, A C, A C)}$ is higher than $F_{\sigma(A, C, A C)}$ as the additional manufacturing costs $\left(f_{m}^{A}\right)$ are generally greater than the additional selling costs $\left(\Delta f_{s}\right)$. So we have the following ranking of the fixed costs for these four strategies:

$$
F_{\sigma(A, C, C)}<F_{\sigma(A, C, A)}<F_{\sigma(A, C, A C)}<F_{\sigma(A, A C, A C)} .
$$

The slope term $(\phi)$ is determined by the unit cost of production (the denominator, $C(.,)$.$) and the size of the markets (the nominator, I^{l}$, adjusted by relevant transport cost $T)$. For strategies $\sigma(A, C, C), \sigma(A, C, A)$ and $\sigma(A, C, A C)$, they have the same unit cost of production, but differ in the size of the market. Assuming that the United States market is sufficiently larger than the China market (i.e., $\frac{I^{A}}{T}>I^{C}$ ), then the slope increases as one moves from $\sigma(A, C, C)$ to $\sigma(A, C, A)$, and to $\sigma(A, C, A C)$. Strategy $\sigma(A, A C, A C)$ has the same size of the markets as strategy $\sigma(A, C, A C)$, but enjoys a lower unit production cost than strategy $\sigma(A, C, A C)$ due to the tariff-jumping assumption. So we have the following ranking of the slope term for these four strategies:

$$
\phi_{\sigma(A, C, C)}<\phi_{\sigma(A, C, A)}<\phi_{\sigma(A, C, A C)}<\phi_{\sigma(A, A C, A C)} .
$$

With inequalities (4) and (5), it follows that the optimal strategy for a foreign affiliate depends on its productivity:

Proposition: Given that neither the American market nor the Chinese market is negligible, foreign affiliates adopting strategy $\sigma(A, A C, A C)$ have 
the highest productivity, followed by those adopting strategy $\sigma(A, C, A C)$, then those adopting strategy $\sigma(A, C, A)$, and finally those adopting strategy $\sigma(A, C, C)$.

Proof: See the Appendix.

In our dataset, foreign affiliates exporting all their output corresponds to those adopting strategy $\sigma(A, C, A)$, foreign affiliates having sales in China and also exporting some of their output correspond to those adopting strategy $\sigma(A, C, A C)$, and finally foreign affiliates selling all their output in China could be those adopting either strategy $\sigma(A, C, C)$ or strategy $\sigma(A, A C, A C)$. The Proposition predicts that foreign affiliates exporting all their output have lower productivity than those having sales in China and also exporting some of their output, which is consistent with our empirical findings reported in Section 3.

Theoretically, however, it is not clear whether foreign affiliates selling all their output in China have higher productivity than the other two types of foreign affiliates, as foreign affiliates selling all their output in China could be the most productive foreign affiliates (i.e., those adopting strategy $\sigma(A, A C, A C))$ or the least productive foreign affiliates (i.e., those adopting strategy $\sigma(A, C, C)$ ). Empirically, using the balanced sample for the period of 1998-2005, we find that foreign affiliates selling all their output in China have the highest productivity among the three types of foreign affiliates, suggesting that foreign affiliates adopting strategy $\sigma(A, A C, A C)$ dominate those adopting strategy $\sigma(A, C, C)$ in our dataset. But in the full sample of firms in 2005, we find that foreign affiliates selling all output in China become less productive than those having both sales in China and exporting some of their output. This implies that those foreign affiliates entering into China after 1998 may predominantly adopt strategy $\sigma(A, C, C)$ in view of the growing market in China, thereby overshadowing those older foreign affiliates using strategy $\sigma(A, A C, A C) .{ }^{16}$

Our theoretical analysis expands the existing literature on exporting behavior (e.g., Melitz, 2003) by incorporating the possibility that firms could set up different stages of production in different countries (à la Grossman, Helpman, and Szeidl, 2006), which is increasingly prevalent in today's globalized economy. The theoretical predictions summarized in the Proposition focus on the exporting behavior of foreign affiliates (namely, those multinationals that have the manufacturing plants in China), and they are different from

\footnotetext{
${ }^{16}$ Future research will be directed at obtaining finer data sets distinguishing foreign affiliates adopting strategy $\sigma(A, A C, A C)$ from those adopting strategy $\sigma(A, C, C)$, and conducting more detailed analysis.
} 
the findings reported in the literature. It should be pointed out, however, that our theoretical framework can generate the same type of predictions on exporting behavior as in the existing literature if it is focused on domestic firms (namely, firms having both design and manufacturing in China). Among this type of firms, it is the less productive ones that have domestic sales only while the more productive ones have both domestic sales and export.

\section{Conclusion}

Firms have increasingly conducted different stages of production in different countries (e.g., Hummels, Ishii, and Yi, 2001; Yi, 2003). In particular, they have set up operations in low-cost countries for labor-intensive production, and then used them as export platforms. As a result, a significant percentage of export from those low-cost countries is made by foreign affiliates in these countries. Despite its importance, however, much of the existing literature has not formally examined the exporting behavior of foreign affiliates.

In this paper, we fill the void by empirically and theoretically investigating the exporting behavior of foreign affiliates. Using annual surveys of manufacturing firms in China for the period of 1998 to 2005, we find that among foreign affiliates in China exporters are less productive than non-exporters, in contrast to the unanimous finding in the literature that exporters are more productive than non-exporters.

To explain this puzzling finding, we build up a standard trade model, with firm heterogeneity and location choices of vertically-related stages of production (e.g., Melitz, 2003; Grossman, Helpman, and Szeidl, 2006). We can show that in equilibrium there are four strategies corresponding to the three types of foreign affiliates observed in our dataset: foreign affiliates selling all their output in China, foreign affiliates exporting all their output, and foreign affiliates having sales in China and exporting some of their output. The comparison among these four strategies in terms of their productivity offers an explanation for our empirical finding that among foreign affiliates exporters are less productive than non-exporters.

Our paper contributes to the growing literature of firm heterogeneity and trade by focusing on the exporting behavior of foreign affiliates, which are increasingly prevalent in today's globalized economy. To the best of our knowledge, our study is the first one reporting that exporters are less productive than non-exporters. In addition, by incorporating into the standard firm heterogeneity model (Melitz, 2003) the possibility that firms could set up different stages of production in different countries (Grossman, Helpman, 
and Szeidl, 2006), we are able to obtain much richer predictions on the relation between firm productivity and exporting behavior. 


\section{References}

[1] Antràs, P. (2003). "Firms, Contracts, and Trade Structure." Quarterly Journal of Economics 118: 1375-1418.

[2] Antràs, P. and E. Helpman (2004). "Global Sourcing." Journal of Political Economy 112: 552-580.

[3] Baldwin, R.E., R. Forslid, P. Martin, G. Ottaviano, and F. RobertNicoud (2003). Economic Geography and Public Policy. Princeton University Press.

[4] Baldwin, J. R. and W. Gu (2003). "Export-market participation and productivity performance in Canadian manufacturing." Canadian Journal of Economics 36(3): 634-657.

[5] Bernard, A. B., J. Eaton, J. B. Jensen, and S. Kortum (2003). "Plants and Productivity in International Trade." American Economic Review 93(4): 1268-1290.

[6] Bernard, A. B. and J. B. Jensen (1995). "Exporters, Jobs, and Wages in the U.S. Manufacturing: 1976-1987." Brookings Papers on Economic Activity: Microeconomics: 67-119.

[7] Bernard, A. B. and J. B. Jensen (1999). "Exceptional Exporter Performance: Cause, Effect, or Both?" Journal of International Economics 47(1): 1-25.

[8] Bernard, A. B. and J. B. Jensen (2004). "Why Some Firms Export." Review of Economics and Statistics 86(2): 561-569.

[9] Bernard, A. B., J. B. Jensen, S. J. Redding, and P. K. Schott (2007). "Firms in International Trade." Journal of Economic Perspectives 21(3): 105-130.

[10] Bernard, A. B., S. J. Redding, and P. K. Schott (2007). "Comparative Advantage and Heterogeneous Firms." Review of Economic Studies 74(1): 31-66.

[11] Bernard, A. B. and J. Wagner (1997). "Exports and Success in German Manufacturing." Weltwirtschaftliches Archiv 133: 134-157.

[12] Blalock, G. and P. J. Gertler (2004). "Learning from exporting revisited in a less developed setting." Journal of Development Economics 75(2): 397-416. 
[13] Clerides, S. K., S. Lach, and J. R. Tybout (1998). "Is Learning by Exporting Important? Micro-Dynamic Evidence from Colombia, Mexico, and Morocco." Quarterly Journal of Economics 113(3): 903-947.

[14] De Loecker, J. (2007). "Do Exports Generate Higher Productivity? Evidence from Slovenia." Journal of International Economics 73(1): 69-98.

[15] Dixit, A.K. and J.E. Stiglitz. (1977). "Monopolistic Competition and Optimum Product Diversity." American Economic Review 67(3): 297308.

[16] Eaton, J., S. Kortum, and F. Kramarz (2004). "Dissecting Trade: Firms, Industries, and Export Destinations." American Economic Review, Papers and Proceedings 94(2): 150-154.

[17] Ekholm, K., R. Forslid, and J. Markusen. (2007). "Export-Platform Foreign Direct Investment." Journal of the European Economic Association 5: 776-795.

[18] Greene, William H. 2008. Econometric Analysis, Prentice Hall.

[19] Greenaway, D. and R. Kneller (2004). "Exporting and Productivity in the United Kingdom." Oxford Review of Economic Policy 20(3): 358371.

[20] Grossman, G. and E. Helpman (2005). "Outsourcing in a Global Economy." Review of Economic Studies 72: 135-160.

[21] Grossman, G., E. Helpman, and A. Szeidl (2006). "Optimal Integration Strategies for the Multinational Firm." Journal of International Economics 70(1): 216-238.

[22] Hummels, D., J. Ishii, and K.M. Yi (2001). "The Nature and Growth of Vertical Specialization in World Trade." Journal of International Economics 54(1), 75-96.

[23] Kneller, R. and M. Pisu (2004). "Export-oriented FDI in the UK." Oxford Review of Economic Policy 20(3): 424-439.

[24] Levinsohn, J. and A. Petrin (2003). "Estimating Production Functions Using Inputs to Control for Unobservables." Review of Economic Studies 70(2): 317-342. 
[25] Lu, J. and B. Xu (2009). "Foreign Direct Investment, Processing Trade, and China's Export Sophistication." China Economic Review, forthcoming.

[26] Manova, K. and Z.W. Zhang (2008). "China's Exporters and Importers: Firms, Products, and Trade Partners", working paper.

[27] Markusen, J. R. (2002). Multinational Firms and the Theory of International Trade. Cambridge, MA, MIT Press.

[28] Melitz, M. J. (2003). "The Impact of Trade on Intra-industry Reallocations and Aggregate Industry Productivity." Econometrica 71(6): 1695-1725.

[29] Olley, G.S. and A. Pakes (1996). "The Dynamics of Productivity in the Telecommunications Equipment Industry." Econometrica 64: 12631297.

[30] Rodrik, D. (2006). "What's So Special about China's Exports?" NBER Working Paper No.11947.

[31] Van Biesebroeck, J. (2005). "Exporting Raises Productivity in SubSaharan African Manufacturing Firms." Journal of International Economics 67(2): 373-391.

[32] Van Biesebroeck, J. (2007). "Robustness of Productivity Estimates." Journal of Industrial Economics 55(3): 529-569.

[33] Van Biesebroeck, J. (2008). "The Sensitivity of Productivity Estimates: Revisiting Three Important Debates." Journal of Business and Economic Statistics 26(3): 311-328.

[34] Wang, Z. and S.J. Wei. (2008). "What Accounts for the Rising Sophistication of China's Exports?" NBER working paper w13771.

[35] Yeaple, S.R. (2003). "The Complex Integration Strategies of Multinationals and Cross Country Dependencies in the Structure of Foreign Direct Investment." Journal of International Economics 60(2): 293-314.

[36] Yi, K.M. (2003). "Can Vertical Specialization Explain the Growth of World Trade?" Journal of Political Economy 111(1): 52-102. 


\section{Appendix}

\section{Proof of Proposition}

Comparing $\pi(\sigma(A, C, A))$ with $\pi(\sigma(A, C, C))$, we can derive the first threshold point:

$$
\Theta_{1}=\frac{\Delta f_{s}}{1-\alpha} \frac{C\left(d^{A}, m^{C}\right)}{\left(\frac{I^{A}}{T}-I^{C}\right)},
$$

which is greater than 0 given that the size of market in the United States is sufficiently larger than that in China (i.e., $\frac{I^{A}}{T}>I^{C}$ ). Thus, we have $\pi(\sigma(A, C, A)) \geq \pi(\sigma(A, C, C))$ when $\Theta \geq \Theta_{1}$, whereas $\pi(\sigma(A, C, A))<$ $\pi(\sigma(A, C, C))$ when $\Theta<\Theta_{1}$.

Comparing $\pi(\sigma(A, C, A))$ with $\pi(\sigma(A, C, A C))$, we can derive the second threshold point:

$$
\Theta_{2}=\frac{f_{s}}{1-\alpha} \frac{1}{I^{C}} C\left(d^{A}, m^{C}\right)>0,
$$

such that $\pi(\sigma(A, C, A C)) \geq \pi(\sigma(A, C, A))$ when $\Theta \geq \Theta_{2}$, whereas $\pi(\sigma(A, C, A C))<$ $\pi(\sigma(A, C, A))$ when $\Theta<\Theta_{2}$.

Comparing $\pi(\sigma(A, C, A C))$ with $\pi(\sigma(A, A C, A C))$, we can derive the third threshold point:

$$
\Theta_{3}=\frac{f_{m}^{A}-\Delta f_{s}}{1-\alpha} \frac{T}{I^{A}} \frac{C\left(d^{A}, m^{C}\right) \cdot C\left(d^{A}, m^{A}\right)}{T C\left(d^{A}, m^{C}\right)-C\left(d^{A}, m^{A}\right)},
$$

which is great then 0 given the tariff-jumping assumption made in the model setup (i.e., $\left.T C\left(d^{A}, m^{C}\right)-C\left(d^{A}, m^{A}\right)>0\right)$ and the assumption $f_{m}^{A}>\Delta f_{s}$. So we have $\pi(\sigma(A, A C, A C)) \geq \pi(\sigma(A, C, A C))$ when $\Theta \geq \Theta_{3}$, whereas $\pi(\sigma(A, A C, A C)) \leq \pi(\sigma(A, C, A C))$ when $\Theta \leq \Theta_{3}$.

It can be shown that, when neither the American market nor the Chinese market is negligible, i.e., $\frac{I^{A}}{I^{A}+I^{C}} \geq \frac{T\left(f_{s}+\Delta f_{s}\right)}{(T+1) f_{s}+T \Delta f_{s}}$ and $\frac{I^{C}}{I^{A}+I^{C}} \geq \frac{f_{s}\left(T C\left(d^{A}, m^{C}\right)-C\left(d^{A}, m^{A}\right)\right)}{T C\left(d^{A}, m^{A}\right)\left(f_{m}^{A}-\Delta f\right)+\left(T C\left(d^{A}, m^{C}\right)-C\left(d^{A}, m^{A}\right)\right) f_{s}}$, we have

$$
\Theta_{3} \geq \Theta_{2} \geq \Theta_{1}>0
$$

With inequality (A.4), it can be shown that

when $\Theta_{1}>\Theta, \sigma(A, C, C)$ is the optimal strategy when $\Theta_{2}>\Theta \geq \Theta_{1}, \sigma(A, C, A)$ is the optimal strategy when $\Theta_{3}>\Theta \geq \Theta_{2}, \sigma(A, C, A C)$ is the optimal strategy when $\Theta \geq \Theta_{3}, \sigma(A, A C, A C)$ is the optimal strategy 
Figure: The trade-off between fixed costs and production efficiency among four strategies

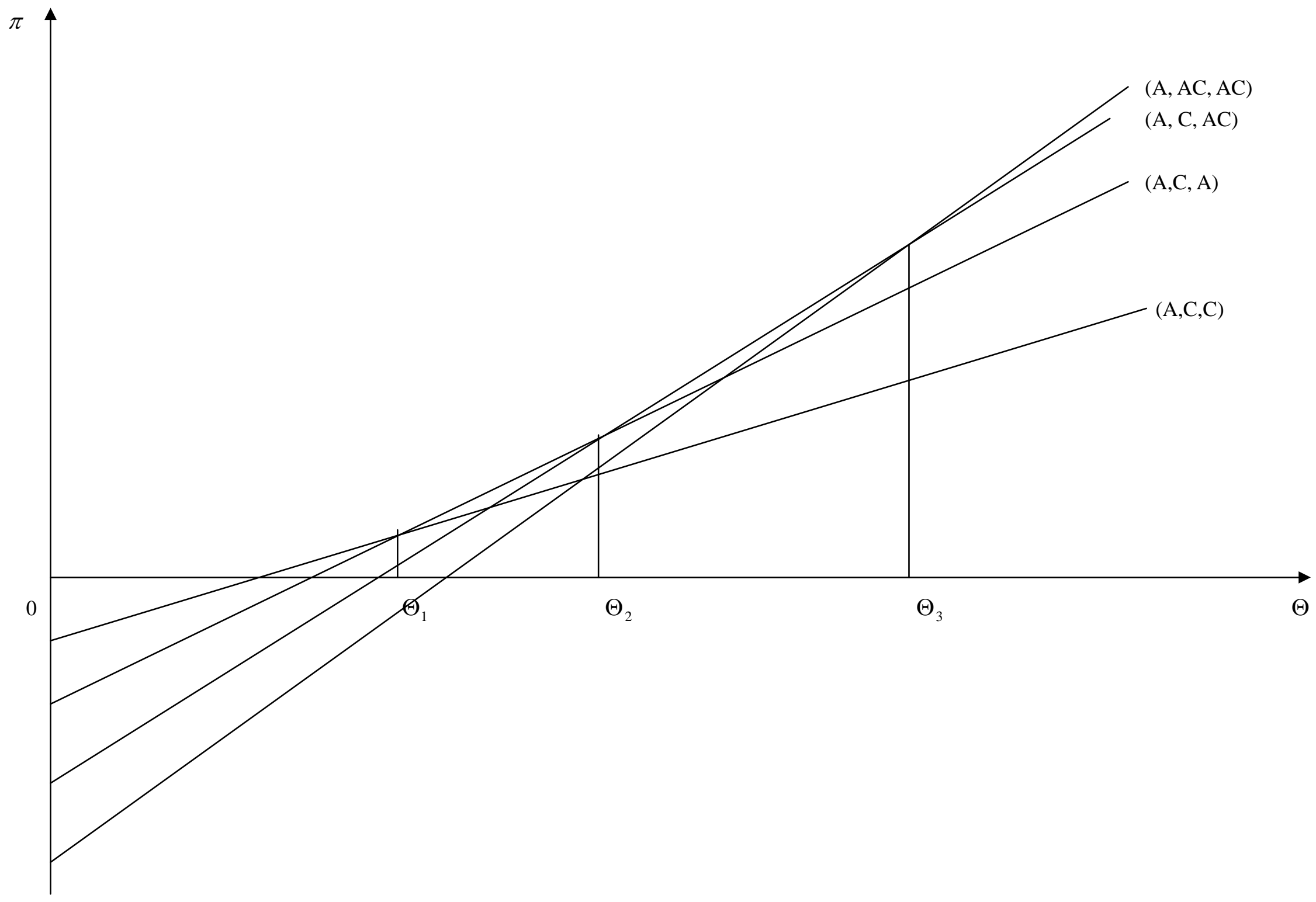


Table 1a: Representativeness of our dataset

\begin{tabular}{|c|c|c|c|c|c|c|c|c|}
\hline & 1998 & 1999 & 2000 & 2001 & 2002 & 2003 & 2004 & 2005 \\
\hline Total export in our dataset (100 million USD) & 1,265 & 1,351 & 1,712 & 1,917 & 2,374 & 3,200 & 3,959 & 5,816 \\
\hline Percentage in China's total export & $69 \%$ & $69 \%$ & $69 \%$ & $72 \%$ & $73 \%$ & $73 \%$ & $67 \%$ & $76 \%$ \\
\hline
\end{tabular}

Note: Data on China's total export come from China Statistical Yearbook (various years).

Table 1b: Exporting behavior of domestic firms and foreign affiliates

\begin{tabular}{|c|c|c|c|c|c|c|c|}
\hline Year & $\begin{array}{l}\text { Percentage of } \\
\text { exporters in all } \\
\text { firms }\end{array}$ & $\begin{array}{l}\text { Percentage of } \\
\text { exporters in } \\
\text { foreign affiliates }\end{array}$ & $\begin{array}{c}\text { Percentage of } \\
\text { exporters in } \\
\text { domestic firms }\end{array}$ & $\begin{array}{l}\text { Percentage of } \\
\text { output exported } \\
\text { in all firms }\end{array}$ & $\begin{array}{l}\text { Percentage of } \\
\text { output } \\
\text { exported in } \\
\text { foreign } \\
\text { affiliates }\end{array}$ & $\begin{array}{l}\text { Percentage of } \\
\text { output exported } \\
\text { in domestic } \\
\text { firms }\end{array}$ & $\begin{array}{c}\text { Percentage of } \\
\text { total export } \\
\text { exported by } \\
\text { foreign affiliates }\end{array}$ \\
\hline 1998 & $24.32 \%$ & $62.03 \%$ & $16.84 \%$ & $18.33 \%$ & $39.23 \%$ & $10.25 \%$ & $59.66 \%$ \\
\hline 1999 & $24.37 \%$ & $61.13 \%$ & $16.63 \%$ & $18.14 \%$ & $37.87 \%$ & $9.96 \%$ & $61.21 \%$ \\
\hline 2000 & $25.83 \%$ & $62.44 \%$ & $17.64 \%$ & $19.43 \%$ & $39.14 \%$ & $10.58 \%$ & $62.42 \%$ \\
\hline 2001 & $26.54 \%$ & $62.89 \%$ & $18.05 \%$ & $19.35 \%$ & $39.02 \%$ & $10.21 \%$ & $63.98 \%$ \\
\hline 2002 & $27.62 \%$ & $63.03 \%$ & $19.17 \%$ & $20.47 \%$ & $41.46 \%$ & $10.51 \%$ & $65.20 \%$ \\
\hline 2003 & $28.32 \%$ & $63.90 \%$ & $19.57 \%$ & $21.32 \%$ & $41.91 \%$ & $10.84 \%$ & $66.30 \%$ \\
\hline 2004 & $29.83 \%$ & $64.12 \%$ & $20.98 \%$ & $22.24 \%$ & $44.35 \%$ & $10.66 \%$ & $68.52 \%$ \\
\hline 2005 & $30.27 \%$ & $64.06 \%$ & $20.53 \%$ & $23.41 \%$ & $44.60 \%$ & $10.83 \%$ & $70.98 \%$ \\
\hline Average & $27.14 \%$ & $62.95 \%$ & $18.68 \%$ & $20.33 \%$ & $40.95 \%$ & $10.48 \%$ & $64.78 \%$ \\
\hline
\end{tabular}


Table 1c: Exporting behavior of domestic firms and foreign affiliates across geographic areas, 2005

\begin{tabular}{|c|c|c|c|c|c|c|}
\hline \multirow[t]{2}{*}{ Area } & $\begin{array}{c}\text { Share in China's total } \\
\text { export }\end{array}$ & $\begin{array}{l}\text { Percentage of } \\
\text { exporters in foreign } \\
\text { affiliates }\end{array}$ & $\begin{array}{l}\text { Percentage of } \\
\text { exporters in domestic } \\
\text { firms }\end{array}$ & $\begin{array}{l}\text { Percentage of output } \\
\text { exported in foreign } \\
\text { affiliates }\end{array}$ & $\begin{array}{l}\text { Percentage of output } \\
\text { exported in domestic } \\
\text { firms }\end{array}$ & $\begin{array}{l}\text { Share of total } \\
\text { export exported by } \\
\text { foreign affiliates }\end{array}$ \\
\hline & 1 & 2 & 3 & 4 & 5 & 6 \\
\hline $\begin{array}{l}\text { Coastal } \\
\text { Central }\end{array}$ & $\begin{array}{l}93.8 \% \\
4.5 \%\end{array}$ & $\begin{array}{l}66.0 \% \\
41.6 \%\end{array}$ & $\begin{array}{l}22.0 \% \\
23.2 \%\end{array}$ & $\begin{array}{l}47.1 \% \\
13.7 \%\end{array}$ & $\begin{array}{l}13.2 \% \\
5.3 \%\end{array}$ & $\begin{array}{l}71.4 \% \\
27.6 \%\end{array}$ \\
\hline Western & $1.7 \%$ & $30.2 \%$ & $8.2 \%$ & $9.3 \%$ & $4.7 \%$ & $17.1 \%$ \\
\hline \multicolumn{7}{|c|}{$\begin{array}{l}\text { Note: Numbers in column } 1 \text { represent accumulated shares in China’s total export for corresponding areas, while numbers in other columns represent simple } \\
\text { averages of values for the corresponding areas. Coastal area includes Liaoning, Beijing, Tianjin, Hebei, Shandong, Jiangsu, Shanghai, Zhejiang, Fujian, } \\
\text { Guangdong, Guangxi, and Hainan; Central area includes Heilongjiang, Jilin, Inner Mongolia, Shanxi, Henan, Anhui, Hubei, Hunan, and Jiangxi; and Western } \\
\text { area includes Shaanxi, Gansu, Ningxia, Qinghai, Xinjiang, Guizhou, Yunnan, Chongqing, Sichuan, and Tibet. }\end{array}$} \\
\hline \multicolumn{7}{|c|}{ Table 1d: Exporting behavior of domestic firms and foreign affiliates across industries, 2005} \\
\hline \multirow{3}{*}{$\begin{array}{l}\text { ECD R\&D } \\
\text { Eegorized by } \\
\text { ensty standard } \\
\end{array}$} & & & & \multirow{2}{*}{\multicolumn{3}{|c|}{$\begin{array}{l}\text { Percentage of output Percentage of output Share of total export } \\
\text { exported in foreign exported in domestic exported by foreign } \\
\text { affiliates }\end{array}$}} \\
\hline & $\begin{array}{c}\text { Share in China's } \\
\text { total export }\end{array}$ & $\begin{array}{l}\text { Percentage of } \\
\text { exporters in foreign } \\
\text { affiliates }\end{array}$ & $\begin{array}{l}\text { Percentage of } \\
\text { exporters in } \\
\text { domestic firms }\end{array}$ & & & \\
\hline & 1 & 2 & 3 & 4 & 5 & 6 \\
\hline h & $51.8 \%$ & $65.0 \%$ & $19.9 \%$ & $55.3 \%$ & $13.4 \%$ & $82.8 \%$ \\
\hline dium & $16.2 \%$ & $53.2 \%$ & $15.7 \%$ & $20.9 \%$ & $7.1 \%$ & $46.6 \%$ \\
\hline w & $32.0 \%$ & $68.7 \%$ & $25.4 \%$ & $44.1 \%$ & $13.0 \%$ & $56.4 \%$ \\
\hline
\end{tabular}


Table 1e: Exporting behavior of foreign affiliates

\begin{tabular}{|c|c|c|c|}
\hline Year & $\begin{array}{c}\text { Percentage of foreign affiliates selling all their } \\
\text { output in China }\end{array}$ & $\begin{array}{l}\text { Percentage of foreign affiliates having sales in } \\
\text { China and also exporting some of their output }\end{array}$ & $\begin{array}{c}\text { Percentage of foreign affiliates exporting all } \\
\text { their output }\end{array}$ \\
\hline 1998 & $37.97 \%$ & $36.27 \%$ & $25.76 \%$ \\
\hline 1999 & $38.87 \%$ & $37.10 \%$ & $24.04 \%$ \\
\hline 2000 & $37.56 \%$ & $37.75 \%$ & $24.69 \%$ \\
\hline 2001 & $37.11 \%$ & $38.76 \%$ & $24.14 \%$ \\
\hline 2002 & $36.97 \%$ & $39.52 \%$ & $23.51 \%$ \\
\hline 2003 & $36.10 \%$ & $40.17 \%$ & $23.73 \%$ \\
\hline 2004 & $35.88 \%$ & $43.04 \%$ & $21.08 \%$ \\
\hline 2005 & $35.94 \%$ & $41.19 \%$ & $22.87 \%$ \\
\hline Average & $37.05 \%$ & $39.22 \%$ & $23.73 \%$ \\
\hline
\end{tabular}


Table 2: Benchmark results

\begin{tabular}{|c|c|c|c|c|c|c|c|}
\hline $\begin{array}{l}\text { Sample } \\
\text { Dependent variable }\end{array}$ & $\begin{array}{c}1 \\
\text { Full sample }\end{array}$ & $\begin{array}{c}2 \\
\text { Domestic firms } \\
\text { TFP OLS }\end{array}$ & $\begin{array}{c}3 \\
\text { Foreign affiliates }\end{array}$ & $\begin{array}{c}4 \\
\text { Foreign affiliates } \\
\text { TFP LP }\end{array}$ & $\begin{array}{c}5 \\
\text { Foreign affiliates } \\
\text { TFP OLS }\end{array}$ & $\begin{array}{c}6 \\
\text { Foreign affiliates } \\
\text { TFP OLS }\end{array}$ & $\begin{array}{c}7 \\
\text { Foreign affiliates } \\
\text { TFP LP }\end{array}$ \\
\hline Export & $\begin{array}{l}0.023^{\star \star \star} \\
(0.003)\end{array}$ & $\begin{array}{c}0.035^{\star \star *} \\
(0.004)\end{array}$ & $\begin{array}{l}-0.013^{\star \star} \\
(0.006)\end{array}$ & $\begin{array}{c}-0.030^{\star \star \star} \\
(0.008)\end{array}$ & $\begin{array}{c}-0.010^{\star \star} \\
(0.005)\end{array}$ & $\begin{array}{l}-0.009^{\star} \\
(0.005)\end{array}$ & $\begin{array}{c}-0.031^{\star * *} \\
(0.008)\end{array}$ \\
\hline Industry dummy & Yes & Yes & Yes & Yes & Yes & Yes & Yes \\
\hline Region dummy & Yes & Yes & Yes & Yes & Yes & Yes & Yes \\
\hline Year dummy & Yes & Yes & Yes & Yes & Yes & Yes & Yes \\
\hline Number of observations & 222,784 & 161,560 & 61,224 & 46,712 & 46,712 & 61,156 & 39,328 \\
\hline R-squared & 0.2710 & 0.2655 & 0.2999 & 0.1397 & 0.3390 & 0.3386 & 0.1469 \\
\hline$p$-value for F-test & 0.0000 & 0.0000 & 0.0000 & 0.0000 & 0.0000 & 0.0000 & 0.0000 \\
\hline
\end{tabular}

Note: Robust-standard errors, clustered at the firm-level, are reported in the parenthesis. *, ${ }^{* *}$ and ${ }^{* * *}$ denote the statistical significance at the $10 \%, 5 \%$ and $1 \%$ level, respectively. 
Table 2: Benchmark results, cont.

\begin{tabular}{|c|c|c|c|c|c|}
\hline $\begin{array}{l}\text { Sample } \\
\text { Dependent variable }\end{array}$ & $\begin{array}{c}8 \\
\text { TFP OLS }\end{array}$ & $\begin{array}{c}9 \\
\text { TFP LP }\end{array}$ & $\begin{array}{c}10 \\
\text { Foreign affiliates } \\
\text { TFP OLS }\end{array}$ & $\begin{array}{c}11 \\
\text { TFP OLS }\end{array}$ & $\begin{array}{c}12 \\
\text { TFP LP }\end{array}$ \\
\hline $\begin{array}{l}\text { Domestic sales only } \\
\text { Export only }\end{array}$ & $\begin{array}{c}0.004 \\
(0.007) \\
-0.043^{\star * \star} \\
(0.007) \\
\end{array}$ & $\begin{array}{c}0.027^{\star \star \star} \\
(0.008) \\
-0.019 * \star \\
(0.008) \\
\end{array}$ & $\begin{array}{c}0.002 \\
(0.008) \\
-0.042^{\star \star \star} \\
(0.008) \\
\end{array}$ & $\begin{array}{c}0.001 \\
(0.007) \\
-0.037^{\star \star \star} \\
(0.007) \\
\end{array}$ & $\begin{array}{c}0.028^{\star \star \star} \\
(0.006) \\
-0.013^{\star \star} \\
(0.006) \\
\end{array}$ \\
\hline $\begin{array}{l}\text { Industry dummy } \\
\text { Region dummy } \\
\text { Year dummy } \\
\text { Number of observations } \\
\text { R-squared } \\
p \text {-value for F-test }\end{array}$ & $\begin{array}{c}\text { Yes } \\
\text { Yes } \\
\text { Yes } \\
61,224 \\
0.3009 \\
0.0000\end{array}$ & $\begin{array}{l}\text { Yes } \\
\text { Yes } \\
\text { Yes } \\
46,712 \\
0.1400 \\
0.0000\end{array}$ & $\begin{array}{c}\text { Yes } \\
\text { Yes } \\
\text { Yes } \\
46,712 \\
0.3399 \\
0.0000\end{array}$ & $\begin{array}{l}\text { Yes } \\
\text { Yes } \\
\text { Yes } \\
61,156 \\
0.3392 \\
0.0000\end{array}$ & $\begin{array}{l}\text { Yes } \\
\text { Yes } \\
\text { Yes } \\
39,328 \\
0.1471 \\
0.0000\end{array}$ \\
\hline
\end{tabular}


Table 3: Estimation results using the full sample of firms in 2005

\begin{tabular}{|c|c|c|}
\hline $\begin{array}{l}\text { Sample } \\
\text { Dependent variable }\end{array}$ & 1 For & tes $^{2}$ \\
\hline $\begin{array}{l}\text { Export } \\
\text { Domestic sales only } \\
\text { Export only }\end{array}$ & $\begin{array}{l}-0.0003 \\
(0.003)\end{array}$ & $\begin{array}{c}-0.007^{\star *} \\
(0.003) \\
-0.024^{\star \star *} \\
(0.003) \\
\end{array}$ \\
\hline $\begin{array}{l}\text { Industry dummy } \\
\text { Region dummy } \\
\text { Year dummy } \\
\text { Number of observations } \\
\text { R-squared } \\
p \text {-value for F-test }\end{array}$ & $\begin{array}{c}\text { Yes } \\
\text { Yes } \\
\text { Yes } \\
49,836 \\
0.5215 \\
0.0000\end{array}$ & $\begin{array}{c}\text { Yes } \\
\text { Yes } \\
\text { Yes } \\
49,836 \\
0.5219 \\
0.0000\end{array}$ \\
\hline
\end{tabular}

Note: Robust-standard errors, clustered at the firm-level, are reported in the parenthesis. ${ }^{* *}$ and ${ }^{* * *}$ denote the statistical significance at the $5 \%$ and $1 \%$ level, respectively. 
Table 4: Robustness checks

\begin{tabular}{|c|c|c|c|c|}
\hline $\begin{array}{l}\text { Specification } \\
\text { Dependent variable }\end{array}$ & $\begin{array}{c}1 \\
\text { Alternative } \\
\text { definition of } \\
\text { foreign affiliates }\end{array}$ & $\begin{array}{r}2 \\
\text { Exclusion of } \\
\text { outlying } \\
\text { observations } \\
\mathrm{T} \\
\end{array}$ & $\begin{array}{c}3 \\
\text { Inclusion of firm } \\
\text { size } \\
\text { LP }\end{array}$ & $\begin{array}{c}4 \\
\text { Estimating TFP } \\
\text { only using } \\
\text { foreign affiliates }\end{array}$ \\
\hline $\begin{array}{l}\text { Domestic sales only } \\
\text { Export only }\end{array}$ & $\begin{array}{c}0.032^{\star \star \star} \\
(0.007) \\
-0.028^{\star \star \star} \\
(0.007) \\
\end{array}$ & $\begin{array}{c}0.024^{\star \star \star} \\
(0.006) \\
-0.021^{\star \star \star} \\
(0.006) \\
\end{array}$ & $\begin{array}{c}0.016^{\star *} \\
(0.008) \\
-0.026^{\star \star \star} \\
(0.008) \\
\end{array}$ & $\begin{array}{c}0.029 * \star \star \\
(0.008) \\
-0.019 * \star \\
(0.008) \\
\end{array}$ \\
\hline $\begin{array}{l}\text { Industry dummy } \\
\text { Region dummy } \\
\text { Year dummy } \\
\text { Number of observations } \\
\text { R-squared } \\
p \text {-value for F-test }\end{array}$ & $\begin{array}{l}\text { Yes } \\
\text { Yes } \\
\text { Yes } \\
57,936 \\
0.1314 \\
0.0000\end{array}$ & $\begin{array}{l}\text { Yes } \\
\text { Yes } \\
\text { Yes } \\
45,777 \\
0.1769 \\
0.0000\end{array}$ & $\begin{array}{l}\text { Yes } \\
\text { Yes } \\
\text { Yes } \\
46,712 \\
0.1428 \\
0.0000\end{array}$ & $\begin{array}{c}\text { Yes } \\
\text { Yes } \\
\text { Yes } \\
46,712 \\
0.1396 \\
0.0000\end{array}$ \\
\hline
\end{tabular}

Note: Robust-standard errors, clustered at the firm-level, are reported in the parenthesis. ${ }^{* *}$ and *** denote the statistical significance at the $5 \%$ and $1 \%$ level, respectively. 